\title{
Where the Human Societies Have To Go?-To the Consciousness Development of Post-Modern Society
}

\author{
Wu-Xun Su \\ Information College of Huaqiao University \\ Quanzhou, Fujian, China, 362021 \\ suwuxun6789@vip.163.com
}

\author{
Teng-xiong Wei \\ Information College of Huaqiao University \\ Quanzhou, Fujian, China, 362021
}

\begin{abstract}
Keeping strong attention to the consciousness development of human society, the author presents here a brief theory outline on the consciousness development of human postmodern society. The inherent basis and the strong power the post-modern society must be consciously developed are put forward and the real socialism production mode is present here for the first time. It's also pointed out that only the real socialism production relation is the most effective mode of production to drive the development of the socialized great productivity. The author also presents here that only the most sufficient social freedom and democracy system can make the most members of the society have own social and historical consciousness through the participating in the local area and whole state public practice and form the social force that have most full consciousness of social historical development and could take the leadership power of the society through the democracy political system and realize the conscious development of human society. Also for the first time the author puts forward that the ultimate object of the consciously development of the human society is to consciously develop the biological species of human beings-self. So the human society must be consciousness to provide the simulative environment for the evolution of human beings and improve or create the universe environment suitable for survival and development of human beings.
\end{abstract}

Keywords-Transfer from spontaneous development to conscious development, Consciousness development of the human society, Real socialism production mode, Social freedom and democracy, Ultimate object of consciously development of human society, Consciousness development of current china

\section{INTRODUCTION}

Human society has entered the 21th century, the "open and reform" of current China also has passed 30 years, where the human society and world have to go is a great question faced the world. The author present here his opinion and hope that it will give some help to the world.

\section{The SPONTANEOUS DEVELOPMENT OF HuMAN SOCIETY}

When the life-forms evolve into the human stage, the human beings have the self-determined, often and conscious libido for the first time in the biology evolution progress. This is the most primal consciousness of human beings in his biological nature and hence the love becomes the one of the forever topics of human society. Along with his developed brain, human beings become the dominative species on the Earth gradually.
Along with the development of productive forces except fulfilling the most essential survival conditions, the human beings become having some residuals. Thereafter the human beings' consciousness pursuing to matter possession---the consciousness of human beings in second level---drive the spontaneous development of human society.

The spontaneous development of human society has gone through different social phases. Because of different geographical, natural conditions and developing paths, there have formed the anfractuous situations in the world, where different areas, nation and country at different developing phases respectively.

The general development law, developing course and its finally ended configuration of human spontaneous society is just as the following statement pointed out by the Marx in the Preface of animadvert on the political economics in 1859[1].

Why we said this classical statement of Marx is the spontaneous development law of human society? That is because in it the basic development power of the human society is the spontaneous developing of productive forces; meanwhile the intention and consciousness only the human owns still not emerged on the consciousness developing of society, so it is impossible to drive the society developing according to the consciousness development law of human society.

\section{The Consciousness DeVelopment PERIOD OF HuMAN SOCIETY AND ITS BASIC DEVELOPMENT LAW}

The productive forces developed in the bourgeois society and pointed out by the Marx in the former quotation are the socialized great productivity, which are established and developed on the basis of the development of modern natural science and technology. Compared with former small-scale production, the dimensions of socialized great productivity are unprecedented. The essential characteristics of the socialized great productivity are that: at first it needs divisions and collaborations in the whole society, then its development must be based on the basis of the development of natural science and technology, meanwhile various factors must be consciously organized in the society-scale and then the productivity could form. In other words the developing of the socialized great productivity must be based on the basis of the developments of science (including the social and natural science, the same below and not mentioned again) and technology. Because of 
this essentiality socialized great productivity can't develop spontaneously; it must develop in consciousness way, whether the human society is or is not conscious to it. So the modern human society or post-modern society, which is both based on the socialized great productivity, must inevitably follow the consciousness development law of the human society. But there are still few people yet to be cognizant of the consciousness development law of the human society and apply it to promote the development of their homeland, own area, nation or race.

The consciousness development law of the human society is as follows: the consciousness development of human society must be based on the socialized great productivity, which is based on the modern science and technology. The consciousness developing society must select some development results of science and technology consciously as the new type of productivity or the updates and reconstructions of former productivity in the course of prompting, advancing and developing the new science and technology. The meaning of the consciously selecting is that on the developing level of science and technology of the time, forecasting the various effects on social life of the adoptions of these results---for example, the effect on the development of productivity it-self, on the organizing of the production relation, on the requirements of various social resource hence demanded, on the influences to the Earth environment, on the developing of human beings-self and so on, and then consciously selecting the most favorable and optimized technology systems to the social conditions of then and there. Meanwhile applying the powers of the superstructure consciously to establish the new type production relation for the most favorable and optimized technology system, which is the evolution forms of it and to invoke various social resources, adjust social relations and alter peoples thoughts for it and so on. To sum up, cutting out the capacious social space for the development of the new type productivity and constantly drive the human society on the consciousness developing way in which the Earth environment is being optimized and the developing and evolving of the human beings-self is being stimulated in scientific mode.

So the essential preconditions of the consciously developing society must be that: there would be most abroad, embedded freedom of thinking, opinion expressing and politics in the society and exist fully developed modern times democracy system; because only these conditions exist, can the enthusiasm, creativity and consciousness of all members of the society be fully spew out and then the formation of the consciousness research and research troops of the social and natural science can be made---especially the troops of social science and the formation of the social political forces, which is consciousness of the law of the human society development, can be made and through the modern democracy system the consciousness social forces have the chance to hold the leader hegemony of the society on different developing stage and lead the society to realize the consciousness development.

The society consciousness development, of course, must be implemented under the leadership of the consciousness social forces. The peoples, which really master the soul of human beings' advanced culture and Marxism---materialist dialectics and combine it with the social and historical reality and can apply the human society development law to drive the society developing, can hold the leader hegemony of the society is the necessary condition of the consciousness development for a zone, country, nation and race.

\section{The APPROPRIATE CONFIGURATION OF HuMAN POST- MODERN SOCIETY THE WORLD HAS TO GO}

Running to now the human society has entered the global times. Although various countries, nations and areas are at different development stages, but due to the rapid and relatively accelerated developing of science and technology the distinctions between different echelons are gradually smaller and smaller and the interactions between the advanced and relatively laggard areas and societies are stronger and stronger. The most advanced area and countries in the world are entering the post-modern society. From the point of view of the society consciousness development the appropriate configuration of human post-modern society will play great role in promoting the human society into the consciously developing period. In other words, the world has to construct the appropriate configuration of human post-modern society and gradually develop it into the consciousness developing period of human society.

\section{A. The Advanced Political System-The Full and Most Extended Social Freedom and Democracy System}

The combination of population distributing in clime section and in vertical social systems is the inherent basis of reasonable election method of public opinion representative of modern society. That also must be the reasonable basis of post-modern representative system state. Because the consciousness centralized the desires of whole citizens and country is always far more advance and higher than it of the self-righteous cliquish group. So the state and government based on the modern representative system could be driven or promoted by the social democracy system into the consciousness developing course and gradually realize the consciousness developing of human beings-self. Based on the internet the combination of direct and indirect democracy could be well done and realized the most advanced political system.

That is the most likely approach for human society to enter the consciousness developing period.

\section{B. The Economic Configuration of Post-Modern Society}

The economic configuration of post-modern society should inherit market economic system of modern society because only it can suit people's various different needs of modern society. But it should be changed into the market economic system with consciously macro-economic regulation and control system. The meaning of consciousness regulation and control converges mainly at two aspects: 1 . the consciousness guiding to the applications of new type productivity and its scientific and technological research basis; 2 . the consciousness guiding to the social industries system, scale, the priority of industry development and enterprise innovation system.

It should inherit various production elements market full developed in modern society, the capital market marked by the modern stock market, various developed markets of intellectual 
property rights and manpower resource training and exchanging and so on. It also should inherit the joint-stock system of enterprise organization form, enterprise creating and social burst-up mechanism in modern society in order to encourage the people carving out and when is failure there is a reliable leeway. But, more important, it should consciously reconstruct the various economic forms remained by the modern society and establish the real suitable economic infrastructure to socialized great production forces (Rsei to $S g p f$ )-the real suitable production relation to socialized great production forces (Rspr to Sgpf).

The production relation in post-modern society should gradually put the Rspr to Sgpf into practice because only that production relation is the most effective mode of production to drive the development of the socialized great productivity and hence the development of post-modern society.

What is the real suitable production relation to socialized great production forces ( $\mathrm{Rspr}$ to Sgpf)? According to the original of Marxism, it ought to be like that: In the enterprises organized consciously by the elements of bankroll, manpower resource, technology and management, the bankroll is the conglomeration of foregone labor, using it, of course, must pay out cost (i.e. the interest, in general it has to be lower than the average profit margin of commonly industry); technology is the intellectual property rights, it must be bought from its possessor or be shared through the permission of its possessor and forming the capital of intellectual property rights; manpower resource is the live labor, which, having to under the scientific management and through the technique process, will produce out the various social products and realize the social value so the fore-passed value is implemented in the new productions; when taking out all the production cost (including the interest and expenses of the bankroll and intellectual property rights capital, the wages of all personnel(Note that: the wages should be fully counted-the full cost of reproducing that man resource), ranging from the simple work to the most complex work, including management and innovation, and other revenues necessary to turn into states), there is still remaining benefits, then the benefits are the surplus value created by all of the live labor and should be possessed of by all labor personnel and each should share the benefits according to his contributive proportion; But if there is no remaining benefits, (i.e. the enterprise do not earn and should be deficit), they also must take corresponding economic and social duty of it and each share the duty and charges according to his contributive proportion; that is the truly Rspr to Sgpf principia. So from the point of view of the stabilization, development and social insurance, the enterprises earning benefits should leave behind certain proportion social safety and bankruptcy fund for all social enterprises, including it-self, and then allocate the after deducted benefits according to each contributive proportion. The contributive proportion of each personnel in different historical period, of course, has different forms. In the market economics conditions one representation of it is their wages contributive proportion and to allocate the after deducted benefits according to them is one form of the truly Rspr to Sgpf allocation.

In quantity, bankroll, intellectual property rights and manpower resource each should occupy one third of whole shares of the enterprise. (Here we must emphasize that the one third of whole shares of the manpower resource is the right by its own nature, not need by the bankroll investment). That economic system is the most power system to drive the society developing forward.

For example, in current China there is a well-known group-Huawei group, in which the boss only has occupied few percent of shares of the group, exceed $90 \%$ shares are occupied by the manpower resource of the group. Just because of that situation, applying the most advanced economic system-all member are consciously hard working in creative manner--, the Huawei group is the most powerful enterprise group in China, or even in the world, its creativity, developing speed, expending scale and earning capacity and so on, all are on the top grade.

Because all the economic activities have certain cycle on the move, whether the enterprise could earn or not is should have some time to wait to get the results, so the prefer way to allocate the after deducted benefits according to each contributive proportion is to apply the "future rights" principles like the "future stock-holding rights" in some advanced countries for management layer.

On the macro-scale of society the private property rights should be protected but some types of income tax should be collected by the state to adjust the incomes among different layers for reducing the differences between rich and poor.

In the modern highly developed capitalism societies, jointstock enterprises occupy the dominant status and the profits of them are distributed proportionately among shareholders; that is the social capitalism; if they stride forward further and convert the live labor into shares and participate in the distribution of the enterprises' profits, then they stride a big step to the truly Rspr to Sgpf; if the fashion of converting the live labor into shares could be strictly according to the truly Rspr to Sgpf principle[2] and evolving with the times they should be the truly Rspr to Sgpf and consciousness developing society. Historical evolvement is most probably along this way forward.

On the macro-scale the operation and management system of the post-modern society should continue carrying out the consciously regulation and control like discussed above and unlocking in micro-scale on the basis of modern society.

The state should prescribe the various basic systems for the microcosmic enterprises in law (including the compositions, the operating mode, the production relation, the counting of costs and sale prices and so on.); for example prescribe the truly Rspr to Sgpf must be the practical relation in all enterprises, then the Rsei to Sgpf basis should be established [3].

Although the state have prescribed the various basic systems for the microcosmic enterprises in law but the microcosmic enterprises have full freedom to decide what they are going to do according to the join-stock system.

Another important function, perhaps the most important function having been shown by the finance storm, the consciously macro-economic control system should do is to 
balance the real economy and virtual economy and supervise the scale and the types of the derivative economy by finance and securities transactions. From the historical point of view the finance is developed from the serving for the real economy the main functions of which is financing and circulating service. The securities-forming of assets is a progress of market economy. But it should be admitted that the derivative economy by finance and securities transactions is mainly the play garden of rich men and has little association with the serving for the real economy. But the derivative economy by finance and securities transactions, in fact, is derived from the real economy and when the link of which with the real economy can't bear that superstructure, the results not only causes serious effects on the virtual economy it-self but also the real economy. So the consciously macro-economic control system should supervise the main finance factors, including the money supply (the ratio of money supply to national GDP), reference interest rate, stock market index, inflation index, the scale and type of the derivative economy by finance and securities transactions and so on to keep the economy consciously developing.

Except the scope the above mentioned a most important regulation or control in macro-scale market economy is the price supervising (including the supervising to market price, sell price of enterprise products, sudden huge profits of enterprise and industries and so on). That is to establish rigorous price making system so that any enterprise or industry have no chance to get sudden huge profits and the price and its index could become the important reference indexes of the social consciousness supervising systems. In addition the various effective means of indirect regulation and control, for example the supply amount of bankroll, bank interest rate, various tax rate (which adjusting the income fairness in different social layers, including progressive income tax and inheritance tax rate), should be used continuously in order to gradually realize the social fairness and harmoniousness and accelerate the consciousness developing of society in whole.

That truly Rspr to Sgpf is the basis the post-modern society must be carried out.

In current China, under the leadership of the general secretary Xijinping of the Chinese Communist Party (CCP), there are most favorable conditions for China to transform from the spontaneous social developing into the consciously developing. Once the most advanced politic and economic system we described above are established in China, the consciously developing of China will take a big step forward and give the whole world a huge promotion. So establish that most advanced politic and economic system is the objective of the China's reform. The leadership group of CCP is doing that now.

\section{The OBJective of Consciousness DeVELOPMENT OF HUMAN SOCIETY}

When the human society has entered the consciousness developing period, the "prehistoric phases" of human society ends. Then whether it's the highly developed "freedom society" of West or the "communism society" of East, what is the objective of the consciousness development of human society? This is a question, which is not put forward as yet definitely. But it is very important because its solution is the most decisive factor to direct the transfer from the spontaneous development into the consciousness one.

The objective of consciousness development of human society, in the final analysis, is to evolve the species of human beings-self (in the original meaning of biology) and make the human beings be able to adapt the gradual changed Earth universe environment or even to change or create the universe environment the human beings could survive and develop.

Since the fifties of $20^{\text {th }}$ century, when the Watson and Crick discovered the double helix structure of DNA, the researches of human beings on the life germ plasm, the biological macromolecules, biological development course at different level and various life phenomena are all obtain enormous progresses. But due to the highly complexity of the life processes even at the present when the gene atlas of human beings is completely derived, the human beings are still sciolism and have little main threads before the "Heaven book" of the full series of the human beings genes[4].

So when has entered the consciousness developing society there are still extensive long course of promoting the consciousness developing of human beings-self in its original biological species meaning. The rapid development of molecular biology and human theory of gene in modern times' world make the beginning of this course. The consciousness of human beings have to develop itself consciously and create various conditions to accelerate the evolutions of itself once becomes the general common understanding of the whole humanity, it's the most strong power to drive the human society developing into the consciousness developing course. Running to the stage and level of the human society and its social productivity of 21th century, the global world has gradually been syncretizing into economic community. At present there have no biological survival worry to the human beings as whole humanity on the Earth. Conversely perhaps the addlepated and non-farseeing activity of human beings could destroy the Earth environment and hence the human beings-self. So the clear-headed and advanced social leaders should lead the human beings make great efforts to the objective of human consciousness developing and realize the developing through the consciousness development of human society.

This is the reason why we emphasize the ultimate goal of the development of human society. In spite of the ultimate object of the West or the communism of East, the ultimate goal of the development of human society always is the consciousness evolving of human beings-self and the improvement or creation of the environment the human lives.

The transfer from present stage into the consciousness developing stage for various countries and nations is certainly on different developing paths. But there is a common point that is consciously to drive the society into the consciousness developing way.

\section{CONCLUSIONS}

Human society is transforming from the spontaneous developing into the consciously developing. The key factors to 
enter the consciously developing is to establish the most advanced politics and economic system (including the truly Rspr to Sgpf).

China has the best chance to realize the transform into the consciously developing at the first time in the world. Because in current China there are rich Ideological resources in Marxism, rich Chinese culture resources, strong politics forces (its representative is the CCP) and powerful economic basis. China will make the great contribution for the human beings development.

\section{REFERENCES}

[1] Karl.Marx: "There are certain relations in the social productions which are formed by the people living in the society and not being changed by their wills and suitable to the certain developing stage of their substance productivity. The summation of those production relations constitutes the social economic configuration---the real base, which the juristic and political superstructure is put on and some certain social consciousness forms are adaptive to. The production mode of substance life restricts the whole process of the society, political and spirit life. Does not the people's consciousness determine the people's existence, on converse, does the people's existence determine the people's consciousness. When the social substance productivity have developed to a certain stage, it will be conflicted with the existed production relations or possessions relations (it just the law term of the production relations), which it still acts in. Then those production relations have changed from the developing forms of the productivity into the shackles of it and the times of the society revolution is coming. Along with the alterations of the economic base the entirely astronomical superstructure also have to be transformed either slowly or quickly. When seeing about those transformations the following two aspects should be always distinguished: one are substance transformations of economic conditions of production which could be clearly pointed by the accuracy of natural sciences, another are the juristic, political, religionary, artistic or philosophic forms, in short, the consciousness forms, which is the people acted and expressed when they wake up to that conflict and do their best to want to overcome it. When we judge one person we can't be according to his own opinion on himself, also when we estimate such a times we can't be according to its social consciousness; on converse the social consciousness should be explained from the antinomy of the substance life and the existed conflict between the society productivity and the production relations. No matter what society configuration the society never be ruined before the entirely productivity the society could contain could be brought into play; and that the new and higher production relations are never emerged before their existent conditions are matured in the afterbirth of the former society. So the human beings always only bring forward the tasks themselves could solve, because when carefully examined the task-itself only could come into being when the substance conditions to solve it are already existed or at least are in the forming process. General speaking the production mode of the Asian, the Archaian, the Feodal and the modern times bourgeois could be viewed as some ages of evolution of society economic configuration. The production relation of bourgeois is the last antagonistic form of society production process, the antagonistic form here mentioned is not the individual person antagonism but the antagonism that grown up from the society living conditions of the individual person; however the society productivity developed in the afterbirth of bourgeois society, at the same time, also creates the conditions to solve that antagonism, so the prehistoric phases of human society are ended by that society configuration." (Note: This preface in English was retranslated from the Chinese edition by the author. The Chinese origin is in p194-195 of vol.2 of The florilegium of Marx and Engels published by the People Press in 1966 in China.)

[2] The motive of establishing the truly Rspr to Sgpf and economic basis is not because of its name or ism, but because based on the modern great productive forces it's the most effective production mode: which could excite mostly the enthusiasm, activity, creativity and consciousness of all social members and drive the society developing rapidly and consciously.

[3] As an initiation of truly Rspr to Sgpf all of the live labor should be taken into the account of shares and participate in the distribution of the enterprises' profits among shareholders. The account of the shares should be taken in one accounting year interval and take the total amount of each element (i.e. bankroll, manpower resource costs-wages, technology and management) as the basis of calculating the proportion of every element. They have strided a big step to the truly Rspr to Sgpf. If the fashion of allocating the after deducted benefits is according to each contributive proportion of all members of the live labor then it would be the strictly truly Rspr to Sgpf. Of course the fashion of allocating the after deducted benefits should be evolving with the times the human post-modern society is consciously developing.

[4] The author has given some problems to show that situations: Only putting forward some questions below, the predicament of human beings before this "Heaven book" is present. For example, the growth of human beings at different age is all has the characters of body and look, which are associated in some degree with his parents; well then where does this stereo information store and how does this stereo information express in the development course and control the course? And how can we associate this stereo information with the gene atlas? These problems are not put forward and studied as yet. Another example is that can the highly nerve actions affect the actions of sub-consciousness nerve system of human beings? If it does, how does it do and by what means? This problem, in philosophy, perhaps is the unknowable problem. Because when you are to study it, you are impossible to distinguish the thinking action and the actions of sub-consciousness nerve system of the same person and the study is insignificant. For aught I know, the human beings only could infer and deduce some estate of itself from the researches on the lower developed animals. It is impossible for human beings to fully cognize itself.

From the point of view of philosophy it has to be like that: the things at lower development stage always need the actions from the alternatives at higher development stage to direct them developing to the higher stage. Of course the things at lower development stage also give some reactions to the alternatives at higher development stage to promote their developing. Thus the interactions of the things at different stages constitute the intricacy and complex situations of the developing collectivities and form the collectivity patterns, in which the changes from quantitative to qualitative and the denial of former negation are integrated and interpenetrated. 